\title{
Acute toxicity and responses of antioxidant systems to dibutyl phthalate in neonate and adult Daphnia magna
}

\author{
Chenchen Shen ${ }^{1}$, Jie Wei Corresp., ${ }^{1}$, Tianyi Wang ${ }^{1}$, Yuan Wang Corresp. 1 \\ ${ }^{1}$ Key Laboratory of Hydrobiology in Liaoning Province, Dalian Ocean University, Dalian, China \\ Corresponding Authors: Jie Wei, Yuan Wang \\ Email address: weijiedlou@foxmail.com, wangyuan@dlou.edu.cn
}

Dibutyl phthalate (DBP) poses a severe threat to aquatic ecosystems, introducing hazards to both aquatic species and human health. The ecotoxic effects of DBP on aquatic organisms have not been fully investigated. This study investigates acute toxicity, oxidative damage, and antioxidant enzyme parameters in neonate and adult Daphnia magna exposed to DBP. The obtained results show comparable DBP toxic responses in neonates and adults. The median lethal concentrations $\left(\mathrm{LC}_{50}\right)$ of DBP in neonates exposed for 24 and $48 \mathrm{~h}$ were 3.48 and $2.83 \mathrm{mg} / \mathrm{L}$, respectively. The $L_{50}$ of adults for the same DBP exposure durations were 4.92 and $4.31 \mathrm{mg} / \mathrm{L}$, respectively. Increased hydrogen peroxide and malondialdehyde were found in neonates and adults at both 24 and $48 \mathrm{~h}$, while the total antioxidant capacity decreased. Superoxide dismutase activity increased significantly in neonates and adults exposed to $0.5 \mathrm{mg} / \mathrm{L} \mathrm{DBP}$, and subsequently diminished at higher DBP concentrations and prolonged exposure. Catalase and glutathione S-transferases activities both decreased markedly in neonates and adults. The changes observed were found to be time and concentration dependent. Overall, these data indicated that the acute toxic effects of DBP exposure on neonates were more pronounced than in adults, and oxidative injury may be the main mechanism of DBP toxicity. These results provide a functional link for lipid peroxidation, antioxidant capacity, and antioxidant enzyme levels in the $D$. magna response to DBP exposure. 
1 Acute toxicity and responses of antioxidant systems to 2 Dibutyl phthalate in neonate and adult Daphnia magna

3 Chenchen Shen ${ }^{1}$, Jie Wei ${ }^{1 *}$, Tianyi Wang ${ }^{1}$ and Yuan Wang ${ }^{1 *}$

4 1. Key Laboratory of Hydrobiology in Liaoning Province, Dalian Ocean University, Dalian, 5 China

$6 \quad$ * Correspondence authors: Jie Wei; Yuan Wang

7 E-mail: weijiedlou@ foxmail.com; wangyuan@dlou.edu.cn

8

\section{Abstract}

Dibutyl phthalate (DBP) poses a severe threat to aquatic ecosystems, introducing hazards to both aquatic species and human health. The ecotoxic effects of DBP on aquatic organisms have not been fully investigated. This study investigates acute toxicity, oxidative damage, and antioxidant enzyme parameters in neonate and adult Daphnia magna exposed to DBP. The obtained results show comparable DBP toxic responses in neonates and adults. The median lethal concentrations (LC50) of DBP in neonates exposed for 24 and $48 \mathrm{~h}$ were 3.48 and $2.83 \mathrm{mg} / \mathrm{L}$, respectively. The $\mathrm{LC}_{50}$ of adults for the same DBP exposure durations were 4.92 and $4.31 \mathrm{mg} / \mathrm{L}$, respectively. Increased hydrogen peroxide and malondialdehyde were found in neonates and adults at both 24 and $48 \mathrm{~h}$, while the total antioxidant capacity decreased. Superoxide dismutase activity increased significantly in neonates and adults exposed to $0.5 \mathrm{mg} / \mathrm{L} \mathrm{DBP}$, and subsequently diminished at higher DBP concentrations and prolonged exposure. Catalase and glutathione S-transferases activities both decreased markedly in neonates and adults. The changes observed were found to be time and concentration dependent. Overall, these data indicated that the acute toxic effects of DBP exposure on neonates were more pronounced than in adults, and oxidative injury may be the main mechanism of DBP toxicity. These results provide a functional link for lipid peroxidation, antioxidant capacity, and antioxidant enzyme levels in the D. magna response to DBP exposure. 


\section{Introduction}

Phthalate esters (PAEs) have been extensively used as plasticizers for polymers, despite their established action as endocrine-disrupting chemicals and their severe impact on human health (Daiem et al. 2012; Fernández et al. 2012). The annual production capacity of PAEs exceeds approximately 8 million tons globally (Wittassek et al. 2011). PAEs can be found in various products, such as toys, personal-care products, pharmaceuticals, medical tubes and devices, packaging, detergents, and food items. However, since PAEs are non-covalently bound to polymer matrices, they can easily disperse and contaminate aquatic ecosystems, via discharges of industrial and agricultural wastewater, sewage sludge, and incorrect disposal of plastic items (Daiem et al. 2012; Zhang et al. 2018).

Dibutyl phthalate (DBP) is the most frequently reported PAE pollutant, and has been detected in a variety of water sources and sediments (Huang et al. 1999). High levels of DBP were reported in the South African Songhua River (3.42-10.2 mg/L) (Fatoki et al. 2010). In China, DBP concentrations detected in the lakes of urban Guangzhou range from 0.94 to $3.60 \mathrm{mg} / \mathrm{L}$ (Zeng et al. 2009). DBP was also the primary pollutant that was detected in a water environment survey of the Yangtze River. Especially, in the Wuhan section, the concentrations of DBP in most of the tested samples exceeded the national water quality criteria (3.0 $\mu \mathrm{g} / \mathrm{L})$ (Fan et al. 2008; Wang et al. 2008). DBP is susceptible to hydrolysis in aquatic ecosystems at a slower rate (C. et al. 1997; Thomsen et al. 1999). The photooxidation half-life for DBP in water has been estimated at 144 days (Staples et al. 1997). It has been reported that the biodegradation half-life of DBP in natural surface water is 1 to 14 days, and the biodegradation half-life in groundwater is 2 to 23 days (C. et al. 1997; Thomsen et al. 1999). Although the utilization of DBP as a plasticizer has been banned in the United States, the United Kingdom, and China, it can still be found in aquatic ecosystems (Lin et al. 2018). The minimum toxic effect concentration of DBP for aquatic species is $100 \mu \mathrm{g} / \mathrm{L}$ (Staples et al. 2010). However, monitoring data in specific areas either reached or exceeded this concentration (Fatoki et al. 2010; Zeng et al. 2009). Aquatic species are continuously exposed to DBP, which affects the health of aquatic organisms through various mechanisms and damages aquatic ecosystems (Brown et al. 1998; Staples et al. 1997; Gu et al. 2017).

Previous risk assessment reports have focused on the detrimental effects of DBP on aquatic animals (Brown et al. 1998; Agus et al. 2015; Li et al. 2015) DBP toxicity is partly a result of its lipophilic nature, resulting in ease of accumulation in animal tissues (Agus et al. 2015; He et al. 2011). DBP has been found to induce acute and chronic toxicity in various aquatic species, such as the yellow perch Perca flavescens, the rainbow trout Oncorhynchus mykiss, the nile tilapia Oreochromis niloticus, the mirror carp Cyprinus carpio, and the red killi fish (Staples et al. 2010; Agus et al. 2015; Khalil et al. 2016). A key detrimental physiological effect of DBP exposure in aquatic organisms is the induction of growth disorders (Janjua et al. 2007), as well as the disruption of both development (Xu et al. 2015) and reproduction (Lu et al. 2017). DBP 
accumulates within organism tissues where it can alter and degrade enzymatic processes, which may lead to cell death (Zhao et al. 2014). Moreover, DBP has been found to promote oxidative damage in the dinoflagellate Gymnodinium breve due to elevated intracellular levels of reactive oxygen species (ROS) (Bie et al. 2012). Accumulated active oxygen oxidize biomacromolecules include nucleic acids, proteins, and lipid, and result in metabolic abnormalities in biochemical reactions in vivo (Hamed et al. 2017). Excessive ROS can subject biological membranes to oxidation, thus attacking their cellular lipid peroxidation. High DBP concentrations were reported to cause oxidative injury and elevated malondialdehyde (MDA) levels in the red tide dinoflagellate Karenia brevis ( $L i$ et al. 2015). To maintain the body's homeostasis and prevent further oxidative injury induced by toxic substances, many organisms have evolved antioxidant defenses (Sen et al. 2010). Active oxygen scavenging systems play a central role in these protective defense responses. ROS are abolished by superoxide dismutase (SOD), catalase (CAT), glutathione peroxidase (GPx), glutathione S-transferase (GST), and non-enzymatic scavengers (Xing et al. 2012). These systems protect cells from oxidative injury caused by a range of stresses, such as exposure to DBP toxicity (Li et al. 2015; Zhao et al. 2014). A previous publication reported that under DBP stress conditions, accumulation of SOD results in the scavenging of ROS in $O$. niloticus (Khalil et al. 2016). DBP stimulated CAT and GSH activities in the flounder Paralichthys olivaceus, thus counteracting the oxidative stress (Kang et al. 2010). A study on the goldfish Carassius auratus (Zhao et al. 2014) showed that oxidative damage was detected in all investigated tissues after $96 \mathrm{~h}$ of DBP exposure. Oxidation-related biomarkers are currently extensively employed to assess exposure levels and harmful effects of pollutants on aquatic organisms (Lacroix et al. 2015; Huang et al. 2016).

Daphnia magna is an extensively located zooplankton species and a critical link in the food webs of freshwater ecosystems. They are a key primary consumer and are a primary food source for various planktivorous fish species (Galdiero et al. 2017). Accordingly, Daphnia are not only a commonly used model organism for toxicological surveys of aquatic ecosystem, but are also considered a valuable indicator species for environmental pollution assessments (Cui et al. 2017). A Previous evaluation of the toxicity effects of phthalates showed that diethylhexyl phthalate (DEHP), DBP, and diethyl phthalate (DEP) had detrimental impacts on the fat metabolism, development, reproduction and lifespan of D. magna (Seyoum et al. 2019). Huang et al. (1998) reported a median lethal concentration $\left(\mathrm{LC}_{50}\right)$ for D. magna under DBP treatment at $24 \mathrm{~h}$ of 8.0 $\mathrm{mg} / \mathrm{L}$ (Huang et al. 1998). The LC 50 of DBP, DEHP, and DEP for D. magna exposed for $48 \mathrm{~h}$ were reported to be $6.78,0.003$, and $90.0 \mathrm{mg} / \mathrm{L}$, respectively (Jonsson et al. 2003). Furthermore, a previous study reported that exposure to $1.8 \mathrm{mg} / \mathrm{L}$ of DBP caused a significant decline in the reproductive rate of D. magna (Mccarthy \& Whitmore 1985). A recent study also investigated independent and co-toxicity mechanisms in both bacteria Photobacterium phosphoreum and D. magna exposed to DBP and copper (Huang et al. 2016). We recently reported that the cat and gst 
111

112

113

114

115

116

117

118

119

120

121

122

123

124

125

126

127

128

\section{9}

130

131

132

133

134

135

136

137

138

139

140

141

142

143

144

145

gene expression levels were notably reduced or increased upon DEHP exposure in D.magna (Wang et al 2018). Organisms in the early developmental stages have been reported to be less tolerant to the detrimental effects of pollutants (Huang et al. 2016). Many recent publications showed the teratogenic nature of DBP, reporting malformations in developing Zebrafish Danio rerio, the African clawed frog Xenopus laevis, and embryos of the polychaete Galeolaria caespitosa (Xu et al. 2015; Gardner et al. 2016; Lu et al. 2017). Environmental exposure may lead to DBP accumulation during the neonatal stage, which negatively impacts various future developmental characteristics (Khalil et al. 2016). Until now, little is known regarding the differences in the deleterious effects of DBP on D. magna in neonatal and adult antioxidant defense systems. Therefore, in parallel tests, this study assessed the sensitivity of D. magna in neonates and adults exposed to the toxic pollutant DBP.

The objectives of the present work are (1) to compare the acute toxicity of D. magna in neonates and adults exposed to DBP, (2) to establish safe concentration of DBP exposure to neonatal and adult D. magna, for the application of risk evaluations of polluted fresh water, (3) to further investigate the mechanism of DBP toxicity by determining its effects on lipid peroxidation and oxidative damage in both neonatal and adult $D$. magna populations. These data provide a reference for the further ecological risk evaluation of PAE exposure of aquatic organisms.

\section{Materials \& methods}

Experimental materials

D. magna were provided by the Key Laboratory of Hydrobiology at Dalian Ocean University (Liaoning Province, China). Neonates or adults that were synchronously released from laboratory-cultured clonal line of D. magna were used for the experiments. The clonal line was initiated with an individual, parthenogenetic female. The neonates produced by this first female were selected and then cultivated. Experiments were performed using 4-6 brooding offspring. The selected neonates or adults were cultured in dechlorinated water in a $500 \mathrm{~mL}$ glass beaker, kept in an illumination incubator (Thermo 3744, Germany). The incubation conditions were adjusted to $22 \pm 2{ }^{\circ} \mathrm{C}$ on an alternate $12 \mathrm{~h}$ light-dark cycle. The light intensity parameter of the experimental animal culture was set to 2000 lux. The total hardness, alkalinity, dissolved oxygen, and $\mathrm{pH}$ of culture water, were $7.29 \pm 0.1 \mathrm{mmol} / \mathrm{L}, 12.48 \pm 0.4 \mathrm{mmol} / \mathrm{L}, 7.96 \pm 0.3 \mathrm{mg} / \mathrm{L}$, and $7.8 \pm$ 0.2 , respectively. Concentrated Scenedesmus sp. cultures were utilized as food for D. magna at a feeding density of $3 \times 10^{5}-4 \times 10^{5} \mathrm{cell} / \mathrm{mL}$.

DBP (CAS No: 84-74-2) was bought from Sinopharm Chemical Reagent Co., Ltd. (Shanghai, China), and was reconstituted with acetone for toxicity experiments.

Acute toxicity assay 
146 The toxicity of DBP was determined after 24 or 48 h of static exposure via acute toxicity test

147 published by OECD (OECD 2004). Newly hatched neonates (length $0.86 \pm 0.08 \mathrm{~mm}$ ) and adults

148 (length $2.67 \pm 0.05 \mathrm{~mm}$ ) were used for the acute toxicity test. The test concentrations of DBP

149 were established based on the data obtained by pre-experimentation and previously reported

150 literature (Adams et al. 2010). DBP concentrations were set to 1, 2, 3, 4, and $5 \mathrm{mg} / \mathrm{L}$. Culture

151 media without added DBP and solvent was used as blank control. A solvent control $(0.008 \%$

152 acetone only treatment, v/v) was also included to determine baseline toxicity. Preliminary

153 experiments and previous literatures confirmed that acetone at $0.008 \%$ had no effect on survival

154 or biochemical responses in D. magna (Sancho et al. 2009; Zhao et al. 2014). Five replicates

155 were conducted per treatment concentration (blank control, solvent control, plus DBP

156 concentrations). For each replicate, 10 D. magna neonates or adults were cultured in a glass

157 beaker containing $100 \mathrm{~mL}$ of DBP solutions or control solutions and 50 organisms were used for

158 each different concentration of DBP. Neither D. magna neonates nor adults were fed during the

159 test. The movement status of D. magna was examined 24 or $48 \mathrm{~h}$ post DBP exposure. D. magna

160 were regarded as immobile if they did not swim $15 \mathrm{~s}$ post gentle agitation.

161 The test compound DBP concentrations were determined by GC/MS mass spectrometry.

162 Nominal and measured concentrations of DBP are presented in Supplemental Table S1. The

163 stability of DBP in different media has been reported previously (Bajt et al. 2001; Zhou et al.

164 2005; Wang et al. 2008). LC50 was defined as the concentration of a substance that induces

165 mortality in $50 \%$ of the test group in a short-term experiment. The safe concentration (SC) of the

166 substance was calculated via Eq. (1) (Sprague 1971):

$$
\mathrm{SC}=\frac{24 \mathrm{hLC}_{50} \times 0.3}{\left(24 \mathrm{hLC}_{50} / 48 \mathrm{hLC}_{50}\right)^{3}}
$$

Sublethal toxicity bioassays

After $\mathrm{LC}_{50}$ values were calculated, D. magna were exposed to sublethal toxic concentrations of

DBP to test both MDA content and antioxidant enzyme activity. Two DBP concentrations (0.5 and $2.0 \mathrm{mg} / \mathrm{L}$ ) were chosen, and both blank control (no DBP no acetone) and solvent control $(0.008 \%$ acetone, $\mathrm{v} / \mathrm{v})$ were included to determine the baseline reads on enzyme activity assays.

For each time endpoint $(0,24$, and $48 \mathrm{~h})$, a corresponding control was performed at the same growth stage as the treatment groups. Each group contained four replicates. For each replicate, 500 neonates were randomly grouped to a beaker containing $5 \mathrm{~L}$ of test solution, and 300 adults were also placed in a different $5 \mathrm{~L}$ glass beaker. Both the neonates and adults were exposed under 
179 standard culture conditions without feeding throughout the experiment duration. 24 or $48 \mathrm{~h}$

180 post-exposure, 200 living organisms were harvested for analysis as one replicate. The collected

181

182

183 live D. magna were first rinsed with distilled water three times prior to pooling in centrifuge tubes $(1.5 \mathrm{~mL})$. All samples used for MDA and enzyme activity analysis were either kept on ice throughout the experiment or at $-20^{\circ} \mathrm{C}$ for long term storage.

Following DBP exposure, each sample was homogenized at a 10\% (w/v) dilution in 1x PBS, and then, the supernatants were obtained after centrifugation at 10,000 r/min for $10 \mathrm{~min}$ by Centrifuge 5804 (Eppendorf, Billerica, USA). The protein content, total antioxidant capacity (T-AOC), MDA, hydrogen peroxide $\left(\mathrm{H}_{2} \mathrm{O}_{2}\right)$, and enzyme activity levels were measured with commercially available kits (Nanjing Jiancheng Institute, China).

\section{Oxidative stress assays (biomarkers)}

To analyze the oxidative stress status of D. magna, the contents of MDA and $\mathrm{H}_{2} \mathrm{O}_{2}$ were measured. The protein content was detected with the Bradford method using BSA as protein standard (Bradford 1976). $\mathrm{H}_{2} \mathrm{O}_{2}$ can be reacted with a chromogenic agent to produce a molybdenic acid-peroxide complex. $\mathrm{H}_{2} \mathrm{O}_{2}$ was detected by measuring the absorbance of the molybdenic acid-peroxide complex at $405 \mathrm{~nm}$ using a $\mathrm{H}_{2} \mathrm{O}_{2}$ assay kit (Jiang et al. 1990). MDA as the final lipid peroxidation product was determined based on the formation of a MDA/thiobarbituric acid (TBA) complex (Dhindsa et al. 1981). $1.5 \mathrm{~mL}$ of D. magna was homogenized with an Ultra-Turrax (IKA) in $1 \mathrm{ml} 0.02 \%$ butylhydroxytoluene methanol solution in Milli-Q water. Then, $3 \mathrm{ml}$ of $1 \%$ phosphoric acid and $1 \mathrm{ml}$ of $1 \%$ TBA solution were added. Mixtures were mixed, incubated for $30 \mathrm{~min}$ at $100{ }^{\circ} \mathrm{C}$, and then cooled on ice for $10 \mathrm{~min}$ before addition of $5 \mathrm{ml}$ butanol. Separation of the organic phase was performed by centrifugation at 10,000 rpm for $15 \mathrm{~min}$ at $4{ }^{\circ} \mathrm{C}$. The supernatant was taken and measured at $532 \mathrm{~nm}$. The obtained results were presented as $\mathrm{nmol} / \mathrm{mg}$ protein. Absorbance values were assessed by spectrophotometer (Thermo Fisher Instruments Inc., Vantaa, Finland).

Measurements of antioxidant parameters

T-AOC was measured as the deoxidation ability of $\mathrm{Fe}^{3+}$ to $\mathrm{Fe}^{2+}$ following the principles reported by Opara et al. (Opara et al. 1999) and were quantified as U/mg protein (each U equals the nmol $\mathrm{Fe}^{3+}$ deoxidated per min per mg protein).

SOD (EC 1.15.1.1) activity was calculated via the ability to inhibit cytochrome $\mathrm{c}$ reduction (Manduzio et al. 2003). Reduced cytochrome $c$ by $\mathrm{O}_{2}{ }^{-}$caused an increased absorbance at $550 \mathrm{~nm}$, which was used to measure SOD activity. Each $1 \mathrm{~mL}$ of the reaction mixture contains $50 \mu \mathrm{M}$ 
213 hypoxanthine, $5.6 \mathrm{mU}$ xanthine oxidase, $10 \mu \mathrm{M}$ cytochrome $c, 50 \mathrm{mM}$ phosphate buffer, and 0.1

214 mM EDTA. The enzyme activity was quantified as U/mg protein. Each SOD unit equals the amount of sample that can inhibit the rate of reduction of cytochrome $c$ by $50 \%$.

CAT (EC 1.11.1.6) activity was assessed following the Aebi method (Aebi 1984). Briefly, 8 $\mu \mathrm{L}$ of extracted protein sample was mixed with $792 \mathrm{~mL}$ of reaction buffer (PBS $10 \mathrm{mM}, \mathrm{H}_{2} \mathrm{O}_{2} 10$ $\mathrm{mM}$ ) in a measuring cuvette and the absorbance was measured at $240 \mathrm{~nm}$ for $1.5 \mathrm{~min}$. The values from CAT enzymatic assay were quantified as units of CAT activity per mg of protein (U/mg protein). Each unit of CAT was determined as the amount of enzyme decomposing $1 \mathrm{mmol}$ of $\mathrm{H}_{2} \mathrm{O}_{2}$ per second.

GST (EC 2.5.1.18) activity was detected by the conjugation of GSH (Habig et al. 1974) using 1-chloro-2, 4 dinitrobenzene (CDNB) (Sigma) as substrate. Briefly, $15 \mu \mathrm{L}$ of the extracted protein sample was mixed with $200 \mu \mathrm{L}$ of reaction buffer, containing $200 \mathrm{mM}$ PBS buffer at $\mathrm{pH}=$ 7.5, 1-glutathione reduced $1 \mathrm{mM}$, and 1-chloro-2, 4-dinitrobenzene (CDNB) $1 \mathrm{mM}$. The absorbance value was measured at $340 \mathrm{~nm}$. One unit of GST was determined as the amount of enzyme capable of catalyzing $1 \mu \mathrm{M}$ of CDNB per minute. The GST activity was quantified as $\mu \mathrm{mol} / \mathrm{min} / \mathrm{mg} / \mathrm{protein}$.

Statistical analysis

Statistical analyses were conducted using SPSS 21. Statistical data were presented as mean values \pm standard deviation (SD) in all studies if not otherwise specified. The $\mathrm{LC}_{50}$ and the $95 \%$ confidence limits were calculated using Probit. The significance of the various parameters was tested using two-way analysis of variance (ANOVA). A $p$ value of 0.05 was used as cutoff for statistical significance, while a $\mathrm{p}$ value of 0.01 for used to indicate high significance. Duncan's multiple range test was used to compare significant differences among treatments.

\section{Results}

239 Acute toxic effects of DBP on D. magna

240 No neonatal and adult mortality were present in controls (deionized water and acetone) after 48-h 241 of testing. Increasing toxicity was observed in neonatal and adult D. magna, with incremental 242 increases in DBP concentration. As shown in Table 1, a notable correlation was found between the 243 logarithm of DBP concentration and D. magna mortality. Under these experimental conditions, the 24424 and $48 \mathrm{~h}-\mathrm{LC}_{50}$ values for DBP exposure of adult D. magna (4.92 and $4.31 \mathrm{mg} / \mathrm{L}$ ) were higher 
245 than those for neonatal D. magna $(3.48$ and $2.83 \mathrm{mg} / \mathrm{L})$. This data suggests that DBP exposure was 246 more toxic to neonates than to adults.

247 The influence of DBP on $\mathrm{H}_{2} \mathrm{O}_{2}$ content in D. magna

248 The obtained data showed that DBP was associated with obvious upregulation of $\mathrm{H}_{2} \mathrm{O}_{2}$ content in 249 both neonates and adults. $\mathrm{H}_{2} \mathrm{O}_{2}$ content in neonates exposed to $0.5 \mathrm{mg} / \mathrm{L} \mathrm{DBP}$ was significantly 250 increased at both 24 and $48 \mathrm{~h}(17.7 \pm 1.7,17.5 \pm 1.1, p<0.01)$. Exposure to $2.0 \mathrm{mg} / \mathrm{L} \mathrm{DBP}$ resulted 251 in elevated $\mathrm{H}_{2} \mathrm{O}_{2}$ content at $24 \mathrm{~h}(8.5 \pm 1.1)$, followed by a notable increase at $48 \mathrm{~h}$ compared to 252 controls $(19.8 \pm 0.8, p<0.01$, Fig. 1A). Following 0.5 or $2.0 \mathrm{mg} / \mathrm{L}$ DBP exposure treatment of $D$. 253 magna, in adults, the (24 and $48 \mathrm{~h}) \mathrm{H}_{2} \mathrm{O}_{2}$ contents increased significantly compared to controls $(p<$ 254 0.05, Fig. 1B). The induction and accumulation of $\mathrm{H}_{2} \mathrm{O}_{2}$ was related to the concentration and 255 treatment time of external DBP.

256 The influence of DBP on lipid peroxidation in D. magna

257 MDA levels in neonatal D. magna exposed to $0.5 \mathrm{mg} / \mathrm{L} \mathrm{DBP}$ were notably elevated at 24 and 48 $258 \mathrm{~h}(15.6 \pm 4.7$ and 10.9 \pm 4.8$)$, compared to controls $(7.1 \pm 1.2,2.6 \pm 0.6, p<0.01$, Fig. 2A). The 259 treatment of neonates with $2.0 \mathrm{mg} / \mathrm{L} \mathrm{DBP}$ after 24 and $48 \mathrm{~h}$ caused 7.8-fold and 25.6-fold increases in MDA levels, respectively ( $p<0.01$, Fig. 2A). The impact of DBP exposure on MDA content in adult D. magna is shown in Fig. 2B. Adults exposed to $0.5 \mathrm{mg} / \mathrm{L} \mathrm{DBP}$ for 24 h showed no change in MDA levels, while exposure for $48 \mathrm{~h}$ notably increased levels compared to control $(4.9 \pm 0.8 v s 2.2 \pm 0.4, p<0.05)$. Treatment with $2.0 \mathrm{mg} / \mathrm{L} \mathrm{DBP}$ significantly elevated adult $D$. magna MDA levels at 24 and $48 \mathrm{~h}(8.5 \pm 1.1$ and $8.7 \pm 0.3, p<0.05)$.

The influence of DBP on T-AOC in D. magna

Following exposure to $0.5 \mathrm{mg} / \mathrm{L}$ DBP, T-AOC levels were significantly reduced in neonates both at 24 and $48 \mathrm{~h}$ compared to control ( $p<0.05$ and $p<0.01$, respectively), while T-AOC were notably decreased after exposure to $2.0 \mathrm{mg} / \mathrm{L} \mathrm{DBP}$ for 24 and $48 \mathrm{~h}$ compared to control $(p<0.01$, Fig. 3A). The effect of DBP on T-AOC in adult D. magna is shown in Fig. 3B. Following 0.5 and $2.0 \mathrm{mg} / \mathrm{L}$ DBP treatments, T-AOC levels significantly decreased both at 24 and $48 \mathrm{~h}(p<0.01)$.

271 DBP induced activity changes of antioxidant enzyme in D. magna

272 The influence of DBP on SOD activity in neonate D. magna is shown in Fig. 4A, where neonates exposed to $0.5 \mathrm{mg} / \mathrm{L} \mathrm{DBP}$ exhibited a notably increased SOD activity at $24 \mathrm{~h}$ (11.9 \pm 0.2$)$, which then significantly decreased at $48 \mathrm{~h}(4.3 \pm 0.2, p<0.01)$. Exposure of neonates to $2.0 \mathrm{mg} / \mathrm{L} \mathrm{DBP}$ for 24 and $48 \mathrm{~h}$ resulted in a significant decrease in SOD activity $(p<0.01)$. The influence of DBP on SOD activity in adult D. magna is shown in Fig. 4B, where exposure to $0.5 \mathrm{mg} / \mathrm{L}$ DBP led to a notable elevation in adult $D$. magna $(24 \mathrm{~h})$ SOD activity $(p<0.01)$. However, by $48 \mathrm{~h}$ SOD activity 
was notably lower compared to controls $(p<0.01)$. Exposure of adult D. magna (24 and $48 \mathrm{~h})$ to $2.0 \mathrm{mg} / \mathrm{L}$ DBP led to a notable reduction in SOD activity compared to control $(p<0.05)$.

Following exposure to $0.5 \mathrm{mg} / \mathrm{L} \mathrm{DBP}$, neonates showed significantly decreased CAT activity at $24 \mathrm{~h}$ and $48 \mathrm{~h}$ compared to control ( $p<0.01$, Fig. 5A). Following $2.0 \mathrm{mg} / \mathrm{L} \mathrm{DBP}$ exposure treatment on $D$. magna, neonates $(24 \mathrm{~h})$ CAT activity was notably reduced $(p<0.01)$. However, CAT activity increased in the 48-h exposure group $(p<0.01)$. The impact of DBP stress on CAT activity for adult $D$. magna is shown in Fig. 5B. In all adult groups exposed to 0.5 or $2.0 \mathrm{mg} / \mathrm{L} \mathrm{DBP}$ $(24,48 \mathrm{~h}$ ), the levels of CAT decreased in comparison to the controls ( $p<0.01$, respectively).

Following $0.5 \mathrm{mg} / \mathrm{L}$ DBP treatment, neonates showed significant increase in levels of GST activity at $24 \mathrm{~h}$, which then significantly decreased in response to prolonged exposure $(48 \mathrm{~h})$ in comparison to control ( $p<0.01$, Fig. 6A). Following exposure to $2.0 \mathrm{mg} / \mathrm{L} \mathrm{DBP}, \mathrm{CAT}$ activity in neonates was clearly reduced at $24 \mathrm{~h}$ compared to controls $(p<0.01)$. No change was found in other neonatal $D$. magna exposure groups. The impact of DBP stress on GST activity in adult $D$. magna is shown in Fig. 6B. Following treatment with 0.5 and $2.0 \mathrm{mg} / \mathrm{L} \mathrm{DBP}$, adult D. magna (24, $48 \mathrm{~h})$ GST activities were all significantly reduced compared to control $(p<0.01)$.

\section{Discussion}

DBP is a unique anthropogenic contaminant that has been listed as a priority pollutant to the environment according to various international organizations; it is particularly toxic to aquatic ecosystems (Agus et al. 2015; Xu et al. 2015). Aquatic species in the early stages of development are more susceptible to the detrimental impacts of pollutants. In invertebrates, DBP has been found to exert toxic effects, inhibiting animal survival and fertility in Daphnia Moina macrocopa (Wang et al. 2011b), altering embryogenesis and larval development in D. rerio (Xu et al. 2015), affecting survival rates and enzyme activities in the goldfish Carassius auratus (Qu et al. 2015), and damaging the defense mechanisms in the giant freshwater prawn Macrobrachium rosenbergii (Sung et al. 2003). However, studies that assess the impact of DBP stress on neonatal and adult $D$. magna survival and antioxidant systems have not been reported. The objectives of the present work were to analyze the acute toxicity and the oxidative stress responses of D. magna neonates and adults exposed to DBP.

Acute toxicity of DBP exposure to neonate and adult of D. magna.

DBP is a commonly detected persistent organic pollutant with detrimental effects on numerous organisms in aquatic environments (Daiem et al. 2012; Gu et al. 2017). Previous reports reported that the harmful impacts of PAEs on juveniles showed age-dependent sensitivities. The statistical changes were often significant and adults were less sensitive than youth (Hutchinson et al. 1998; 
312 Tonk et al. 2012). The $\mathrm{LC}_{50}$ of DBP in neonates were 3.48 and $2.83 \mathrm{mg} / \mathrm{L}$ in response to exposure

313 for 24 and $48 \mathrm{~h}$, and the $\mathrm{LC}_{50}$ of DBP in adults were 4.92 and $4.31 \mathrm{mg} / \mathrm{L}$ after the same stress

314 duration, respectively (Table 1). The data suggests that DBP was more toxic for neonate $D$.

315 magna than for adults, which was consistent with the previously reported results. The $96 \mathrm{~h} \mathrm{LC} \mathrm{L}_{50}$

316 value for DBP exposed to O. niloticus, was $50 \mathrm{mg} / \mathrm{L}$ in adults (Benli et al. 2016) and $11.8 \mathrm{mg} / \mathrm{L}$ in

317 neonates (Khalil et al. 2016). Exposures to DBP in aquatic organisms ranged from 24 to $96 \mathrm{~h}$ and

318 comprised a relatively wide range of $\mathrm{LC}_{50}$ values $\left(10^{2}\right.$ to $\left.10^{5} \mu \mathrm{g} / \mathrm{L}\right)$. The negative impacts of DBP

319 on aquatic organisms appear to be species-dependent. The findings of the current study differ to

320 data reported for $O$. niloticus exposed to DBP, where the $\mathrm{LC}_{50} \mathrm{was} 50 \mathrm{mg} / \mathrm{L}$ for $96 \mathrm{~h}$ of exposure

321 (Benli et al. 2016). Exposure to a mixture of DBP and $\mathrm{Cu}(\mathrm{II})$ increased the toxicity in D. magna

322 by practically two orders of magnitude in P. phosphoreu (Huang et al. 2016). This notable

323 difference may be the result of variations in species, the development stages of the experimental

324 animals, or other abiotic factors such as dissolved oxygen, salinity, light intensity, and

325 temperature.

326 Oxidative stress in DBP exposed D. magna.

327

328

329

330

331

332

333

334

335

336

337

338

339

340

341

342

343

344

345

MDA, ROS, and T-AOC, are widely used as biomarkers to study the harmful effects of environmental pollutants in aquatic organisms (Li et al. 2015; Xing et al. 2012). The increase in $\mathrm{H}_{2} \mathrm{O}_{2}$ was induced via exposure to $0.5 \mathrm{mg} / \mathrm{L}$ DBP in neonates, and significant $\mathrm{H}_{2} \mathrm{O}_{2}$ overproduction was induced by $2.0 \mathrm{mg} / \mathrm{L} \mathrm{DBP}$ in neonates and $0.5 \mathrm{mg} / \mathrm{L} \mathrm{DBP}$ in adults for $24 \mathrm{~h}$ (Fig. 1). Previous research confirmed ROS production as one of the consequences of toxic response to PAEs (Zheng et al. 2013). The $\mathrm{H}_{2} \mathrm{O}_{2}$ content was increased after DBP exposure (Fig. 1), indicating ROS production and severe oxidative stress in neonates and adults. Monitoring T-AOC responses provides a more general indication of the antioxidative-oxidative status of an organism, than measurement of separate oxidants and/or antioxidants. The obtained results showed that T-AOC levels were notably decreased following DBP stress both in neonates and adults (Fig. 3). Increased ROS may oxidize cellular biomacromolecules (nucleotide, protein, and lipids), resulting in oxidative injury in organisms. Previous publications have confirmed DBP induced lipid peroxidation in C. carpio, D. rerio embryos, and C. carpio, where DBP stimulated lipoxygenase activity and consequently increased lipid peroxidation. This study analyzed the degree of lipid peroxidation in D. magna by assessing the levels of MDA. Increased MDA levels in neonate $D$. magna following exposure to 0.5 and $2.0 \mathrm{mg} / \mathrm{L} \mathrm{DBP}$ for 24 and $48 \mathrm{~h}$, and adult $D$. magna following exposure to $0.5 \mathrm{mg} / \mathrm{L} \mathrm{DBP}(48 \mathrm{~h}$ ) and $2.0 \mathrm{mg} / \mathrm{L} \mathrm{DBP}$ (24 and $48 \mathrm{~h}$ ), suggests the induction of lipid peroxidation (Fig. 2). The observed increase in MDA levels indicates that the inducible antioxidant capacity in vivo were insufficient to eliminate excessive oxygen radicals, 
which is supported by the findings of a previously reported study (Agus et al. 2015). The data obtained in this study showed that after 24 and $48 \mathrm{~h}$ of DBP exposure, the accumulation of $\mathrm{H}_{2} \mathrm{O}_{2}$ and MDA in neonates was significantly higher than in adults. The elevation of MDA was not found in adults following $0.5 \mathrm{mg} / \mathrm{L} \mathrm{DBP}$ exposure for $24 \mathrm{~h}$ (Fig. 2B), suggesting that mature antioxidant systems provide effective protection against low DBP stress. Therefore, this implies that DBP induced different effects due to oxidative injury in neonate and adult $D$. magna, where neonate $D$. magna exhibited higher levels of oxidative damage.

Antioxidant parameters in response to DBP stress in D. magna

To eliminate the increased $\mathrm{H}_{2} \mathrm{O}_{2}$ and MDA levels and mitigate oxidative injury due to free radicals, organisms initiate emergency mechanisms such as increasing their cellular levels of antioxidant parameters, such as SOD, CAT, and GST, and reducing endogenous antioxidants (Sen et al. 2010). SOD can catalyze the disproportionation reaction to form $\mathrm{O}_{2}{ }^{-}$into $\mathrm{H}_{2} \mathrm{O}_{2}$, which is a precursor of the $\mathrm{OH}$ radical. SOD activity is commonly classified as the main defense mechanism against oxidative damage in cells caused by increased ROS and lipid peroxidation (Khan 2012). SOD activity was elevated in brains of carp and the neotropical fish Hoplias malabaricus induced by heavy metals, synthetic organic pollutants, and biotoxins (Da et al. 2011; Xing et al. 2012). In the present work, DBP exposure $(0.5 \mathrm{mg} / \mathrm{L})$ notably increased SOD activity compared to control. Increased SOD activity could be an adaptive response of organisms to environmental stress with the aim to reduce cell damage in D. magna. By using active oxygen scavenging enzymes as defense system, organisms can resist increased levels of $\mathrm{O}_{2}^{-}$. Therefore, increased SOD activity following DBP exposure, may be attributed to the cell's adaptive defense mechanism to eliminate surplus $\mathrm{O}_{2}{ }^{-}$. CAT is a key enzymatic antioxidant system, which can eliminate $\mathrm{H}_{2} \mathrm{O}_{2}$ produced from ROS, catalyzed by SOD, and thus alleviate cell damage (Zhao et al. 2014). Many environmental pollutants, such as DBP, heavy metals, and organic pesticides, induced elevated levels of CAT activity in C. carpio, carp, and blue mussels (Xing et al. 2012; Zhao et al. 2014; Lacroix et al. 2015). This study showed that the CAT activity in neonates and adults of $D$. magna significantly reduced in DBP exposure groups. Increased CAT activity is beneficial for the elimination of excess $\mathrm{H}_{2} \mathrm{O}_{2}$ and to reduce the oxidative damage to cells (Gehringer et al. 2004). However, when the CAT $\mathrm{H}_{2} \mathrm{O}_{2}$ elimination capacity was saturated, excess $\mathrm{H}_{2} \mathrm{O}_{2}$ accumulated and CAT activity was restrained, which resulted in cell damage. This study showed that D. magna under DBP stress reduced CAT activity, and significantly increased SOD activity. The activity of CAT was limited by the intracellular excess of $\mathrm{O}_{2}^{-}$, and the presence of $\mathrm{H}_{2} \mathrm{O}_{2}$ inhibited the action of SOD (Xiang et al. 2017). Thus, DBP exposure may produce $\mathrm{O}_{2}^{-}$, resulting in the inhibition of CAT activity, which was also found here.

GST was found to play a primary regulatory role in the redox biochemical reaction cycle of cells; in particular, its antioxidant activity is mainly deactivated by ROS or peroxidation products. 
382 The intracellular free radical $\mathrm{H}_{2} \mathrm{O}_{2}$ can be converted into water and molecular oxygen via the 383 synergistic action of the two antioxidant enzymes CAT and GST (Wang et al. 2011a). In this study, 384 GST activity was suppressed in DBP-stressed D. magna. GST activity in O. niloticus under heavy metal $\mathrm{Cu}$ stress was also notably reduced (Atli \& Canli 2010). A possible explanation is that excessive ROS or severe oxidative injury may lead to GSH depletion and/or disrupted synthesis and inhibition of GST activity. The data suggest that oxidative stress was created in DBP exposed D. magna. The MDA content and the levels of antioxidant parameters depended on both the level of DBP-induced stress and contact time. Under a severe stress environment, ROS exceeded the cellular antioxidant defense capacity, resulting in decreased activity levels of antioxidant enzyme. DBP exposure treatment led to the failure of the antioxidant defense system with changes in lipid peroxidation, which is consistent to previous findings (Oliveira et al. 2012).

\section{Conclusions}

Acute toxicity assays and biochemical analyses were performed to establish the role of oxidative injury in response to DBP stress in neonate and adult D. magna. The data from acute toxic assays indicates that DBP exposure was more toxic to neonates than to adults, and D. magna in the neonatal stage were less tolerant to the impacts of DBP. Increased MDA production levels and decreased T-AOC levels were observed, suggesting that ROS-induced oxidative damage was a main toxic effect of DBP. All observed indicators in response to contamination stress were time and concentration dependent. The observation of deleterious impacts of DBP exposure at low concentrations, poses a significant potential risk to the global environmental health.

\section{References}

Adams WJ, Biddinger GR, Robillard KA, and Gorsuch JW. 2010. A summary of the acute toxicity of 14 phthalate esters to representative aquatic organisms. Environmental Toxicology \& Chemistry 14:1569-1574.

Aebi H. 1984. Catalase in vitro. Methods Enzymol 105:121-126.

Agus HH, Erkmen B, Sümer S, Sepici-Dinçel A, and Erkoç F. 2015. Impact of DBP on histology and expression of HSP 70 in gill and liver tissue of Cyprinus carpio. Molecular biology reports 42:1409-1417.

Atli G, and Canli M. 2010. Response of antioxidant system of freshwater fish Oreochromis niloticus to acute and chronic metal $(\mathrm{Cd}, \mathrm{Cu}, \mathrm{Cr}, \mathrm{Zn}, \mathrm{Fe})$ exposures. Ecotoxicol Environ Saf 73:1884-1889.

Bajt O, Mailhot G, and Bolte M. 2001. Degradation of dibutyl phthalate by homogeneous photocatalysis with $\mathrm{Fe}(\mathrm{III})$ in aqueous solution. Applied Catalysis B Environmental 33:239-248. 
Benli AÇK, Erkmen B, and Erkoç F. 2016. Genotoxicity of sub-lethal di-n-butyl phthalate (DBP) in Nile tilapia (Oreochromis niloticus)/Genotoksičnost subletalne koncentracije di-n-butil ftalata (DBP-a) u nilskoj tilapiji (Oreochromis niloticus). Archives of Industrial Hygiene and Toxicology 67:25-30.

Bie CC, Li FM, Li YY, and Wang ZY. 2012. [Effects of allelochemical dibutyl phthalate on Gymnodinium breve reactive oxygen species]. Environmental Science 33:442.

Bradford MM. 1976. A rapid and sensitive method for the quantitation of microgram quantities of protein utilizing the principle of protein-dye binding. Analytical Biochemistry 72:248-254. BROWN, CROUDACE, C. P, WILLIAMS, N. J, J. M, JOHNSON, and P. A. 1998. The effect of phthalate ester plasticisers tested as surfactant stabilised dispersions on the reproduction of the Daphnia magna. Chemosphere 36:1367-1379.

C. A, PETERSON, D. R, PARKERTON, T. F, and W. J. 1997. The environmental fate of phthalate esters : A literature review. Chemosphere 35:667-749.

Cui R, Chae Y, and An YJ. 2017. Dimension-dependent toxicity of silver nanomaterials on the cladocerans Daphnia magna and Daphnia galeata. Chemosphere 185:205.

Da SC, Oba ET, Ramsdorf WA, Magalhães VF, Cestari MM, Oliveira Ribeiro CA, and Hc SDA. 2011. First report about saxitoxins in freshwater fish Hoplias malabaricus through trophic exposure. Toxicon 57:141-147.

Daiem MMA, Rivera-Utrilla J, Ocampo-Pérez R, Méndez-Díaz JD, and Sánchez-Polo M. 2012. Environmental impact of phthalic acid esters and their removal from water and sediments by different technologies - A review. Journal of Environmental Management 109:164-178. Dhindsa RS, Plumbdhindsa P, and Thorpe TA. 1981. Leaf Senescence: Correlated with Increased Levels of Membrane Permeability and Lipid Peroxidation, and Decreased Levels of Superoxide Dismutase and Catalase. Journal of Experimental Botany 32:93-101.

Dong X, Qiu X, Meng S, Xu H, Wu X, and Yang M. 2018. Proteomic profile and toxicity pathway analysis in zebrafish embryos exposed to bisphenol A and di-n-butyl phthalate at environmentally relevant levels. Chemosphere 193:313-320.

Fan W, Xia X, and Sha Y. 2008. Distribution of Phthalic Acid Esters in Wuhan section of the Yangtze River, China. Journal of Hazardous Materials 154:317-324.

Fatoki OS, Bornman M, Ravandhalala L, Chimuka L, Genthe B, and Adeniyi A. 2010. Phthalate ester plasticizers in freshwater systems of Venda, South Africa and potential health effects. Water $\mathrm{Sa}$ 36:117-125.

Fernández MA, Gómara B, and González MJ. 2012. Occurrence of Phthalates and Their Metabolites in the Environment and Human Health Implications: Springer Berlin Heidelberg.

Galdiero E, Falanga A, Siciliano A, Maselli V, Guida M, Carotenuto R, Tussellino M, Lombardi L, Benvenuto G, and Galdiero S. 2017. Daphnia magna and Xenopus laevis as in vivo models to probe toxicity and uptake of quantum dots functionalized with gH625. Int J Nanomedicine 12:2717-2731.

Gardner ST, Wood AT, Lester R, Onkst PE, Burnham N, Perygin DH, and Rayburn J. 2016. Assessing differences in toxicity and teratogenicity of three phthalates, Diethyl phthalate, 
459

460

461

462

463

464

465

466

467

468

469

470

471

472

473

474

475

476

477

478

479

480

481

482

483

484

485

486

487

488

489

490

491

492

493

494

495

496

497

498

Di-n-propyl phthalate, and Di-n-butyl phthalate, using Xenopus laevis embryos. Journal of Toxicology \& Environmental Health Part A 79:71-82.

Gehringer MM, Shephard EG, Downing TG, Wiegand C, and Neilan BA. 2004. An investigation into the detoxification of microcystin-LR by the glutathione pathway in Balb/c mice. International Journal of Biochemistry \& Cell Biology 36:931-941.

Gu S, Hao Z, Xu Q, Sun C, Mei S, Wang Z, and Li F. 2017. Comparative Toxicity of the Plasticizer Dibutyl Phthalate to Two Freshwater Algae. Aquatic Toxicology 191:122.

Habig WH, Pabst MJ, and Jakoby WB. 1974. Glutathione S-transferases. The first enzymatic step in mercapturic acid formation. Journal of Biological Chemistry 249:7130.

Hamed SM, Zinta G, Klöck G, Asard H, Selim S, and Abdelgawad H. 2017. Zinc-induced differential oxidative stress and antioxidant responses in Chlorella sorokiniana and Scenedesmus acuminatus. Ecotoxicol Environ Saf 140:256-263.

He H, Hu GJ, Sun C, Chen SL, Yang MN, Li J, Zhao Y, and Wang H. 2011. Trace analysis of persistent toxic substances in the main stream of Jiangsu section of the Yangtze River, China. Environmental Science \& Pollution Research International 18:638-648.

Huang B, Li D, and Yang Y. 2016. Joint Toxicity of Two Phthalates with Waterborne Copper to Daphnia magna and Photobacterium phosphoreum. Bulletin of environmental contamination and toxicology 97:380-386.

Huang G, Sun H, Gao J, and Chen Y. 1998. Study on toxic effects of dibutyl phthalate on Daphnia magna. Environmental Chemistry 17:428-433.

Huang GL, Sun HW, and Song ZH. 1999. Interactions Between Dibutyl Phthalate and Aquatic Organisms. Bulletin of Environmental Contamination \& Toxicology 63:759-765.

Janjua NR, Mortensen GK, Andersson AM, Kongshoj B, Skakkebaek NE, and Wulf HC. 2007. Systemic uptake of diethyl phthalate, dibutyl phthalate, and butyl paraben following whole-body topical application and reproductive and thyroid hormone levels in humans. Environmental Science \& Technology 41:5564-5570.

Jonsson, Susanne, Baun, and Anders. 2003. Toxicity of mono- and diesters of o-phtalic esters to a crustacean, a green alga, and a bacterium. Environmental Toxicology \& Chemistry 22:3037-3043.

Jiang ZY, Woollard AC, and Wolff SP. 1990. Hydrogen peroxide production during experimental protein glycation. Febs Letters 268:69.

Kang JC, Junghoon J, Jageun K, Yoohwa K, Soogun J, and Kwanha P. 2010. Anti-oxidative status and hepatic enzymes following acute administration of diethyl phthalate in olive flounder Paralichthys olivaceus, a marine culture fish. Ecotoxicology \& Environmental Safety 73:1449-1455.

Khalil SR, Elhakim YA, and EL-Murr AE. 2016. Sublethal concentrations of di-n-butyl phthalate promote biochemical changes and DNA damage in juvenile Nile tilapia (Oreochromis niloticus). Japanese Journal of Veterinary Research 64:67-80.

Khan RA. 2012. Brain antioxidant markers, cognitive performance and acetylcholinesterase activity of rats: efficiency of Sonchus asper. Behavioral \& Brain Functions 8:21. 
Lacroix C, Richard G, Seguineau C, Guyomarch J, Moraga D, and Auffret M. 2015. Active and passive biomonitoring suggest metabolic adaptation in blue mussels (Mytilus spp.) chronically exposed to a moderate contamination in Brest harbor (France). Aquatic Toxicology 162:126-137.

Li FM, Wu M, Yao Y, Zheng X, Zhao J, Wang ZY, and Xing BS. 2015. Inhibitory effects and oxidative target site of dibutyl phthalate on Karenia brevis. Chemosphere 132:32-39.

Lin L, Dong L, Meng X, Li Q, Huang Z, Li C, Li R, Yang W, and Crittenden J. 2018. Distribution and sources of polycyclic aromatic hydrocarbons and phthalic acid esters in water and surface sediment from the Three Gorges Reservoir. Journal of Environmental Sciences 69:271.

Lu Y, Lin M, and Aitken RJ. 2017. Exposure of spermatozoa to dibutyl phthalate induces abnormal embryonic development in a marine invertebrate Galeolaria caespitosa (Polychaeta: Serpulidae). Aquatic Toxicology 191:189.

Manduzio H, Monsinjon T, Rocher B, Leboulenger F, and Galap C. 2003. Characterization of an inducible isoform of the $\mathrm{Cu} / \mathrm{Zn}$ superoxide dismutase in the blue mussel Mytilus edulis. Aquatic Toxicology 64:73-83.

Mccarthy JF, and Whitmore DK. 1985. Chronic toxicity of di-n-butyl and di-n-octyl phthalate to Daphnia magna and the fathead minnow. Environmental Toxicology \& Chemistry 4:167-179.

OECD. 2004. OECD Guidelines for the Testing of Chemicals. Methods in Molecular Biology 947:37-56.

Oliveira C, Almeida J, Guilhermino L, Soares AM, and Gravato C. 2012. Acute effects of deltamethrin on swimming velocity and biomarkers of the common prawn Palaemon serratus. Aquatic Toxicology 124-125:209.

Opara EC, Abdelrahman E, Soliman S, Kamel WA, Souka S, Lowe JE, and Abdelaleem S. 1999. Depletion of total antioxidant capacity in type 2 diabetes. Metabolism-clinical \& Experimental 48:1414-1417.

Qu R, Feng M, Sun P, and Wang Z. 2015. A comparative study on antioxidant status combined with integrated biomarker response in Carassius auratus fish exposed to nine phthalates. Environmental toxicology 30:1125-1134.

Sancho E, Villarroel MJ, Andreu E, and Ferrando MD. 2009. Disturbances in energy metabolism of Daphnia magna after exposure to tebuconazole. Chemosphere 74:1171-1178.

Sen S, Chakraborty R, Sridhar C, Reddy Y, and De B. 2010. Free radicals, antioxidants, diseases and phytomedicines: Current status and future prospect. International Journal of Pharmaceutical Sciences Review \& Resear 3:91-100.

Seyoum, A. and Pradhan A. 2019. Effect of phthalates on development, reproduction, fat metabolism and lifespan in Daphnia magna. Science of the Total Environment 654: 969-977.

Sprague JB. 1971. Measurement of pollutant toxicity to fish-III : Sublethal effects and "safe" concentrations. Water Research 5:245-266. 
Staples CA, Adams WJ, Parkerton TF, Gorsuch JW, Biddinger GR, and Reinert KH. 2010. Aquatic toxicity of eighteen phthalate esters. Environmental Toxicology \& Chemistry 16:875-891.

Staples CA, Adams WJ, Parkerton TF, Gorsuch JW, and Reinert KH. 1997. Aquatic toxicity of eighteen phthalate esters. Environmental Toxicology \& Chemistry 16:875-891.

Sung HH, Kao WY, and Su YJ. 2003. Effects and toxicity of phthalate esters to hemocytes of giant freshwater prawn, Macrobrachium rosenbergii. Aquatic Toxicology 64:25-37.

Thomsen M, Rasmussen AG, and Carlsen L. 1999. SAR/QSAR approaches to solubility, partitioning and sorption of phthalates. Chemosphere 38:2613-2624.

Tonk ECM, Aart V, Gremmer ER, Henk VL, and Piersma AH. 2012. Relative sensitivity of developmental and immune parameters in juvenile versus adult male rats after exposure to di(2-ethylhexyl) phthalate. Toxicol Appl Pharmacol 260:48-57.

Wang F, Xia X, and Sha Y. 2008. Distribution of phthalic acid esters in Wuhan section of the Yangtze River, China. Journal of Hazardous Materials 154:317-324.

Wang HF, Zhong XH, Shi WY, and Guo B. 2011a. Study of malondialdehyde (MDA) content, superoxide dismutase (SOD) and glutathione peroxidase (GSH-Px) activities in chickens infected with avian infectious bronchitis virus. African Journal of Biotechnology 10:9213-9217.

Wang JX, Xi YL, Hu K, and Liu XB. 2011b. Effect of butyl benzyl phthalate on life table-demography of two successive generations of cladoceran Moina macrocopa Straus. Journal of Environmental Biology 32:17-22.

Wang P, ., Wang SL, and Fan CQ. 2008. Atmospheric distribution of particulate- and gas-phase phthalic esters (PAEs) in a Metropolitan City, Nanjing, East China. Chemosphere 72:1567-1572.

Wang Y, Wang T, Ban Y, Shen C, Shen Q, Chai X, Zhao W, and Wei J. 2018. Di-(2-ethylhexyl) Phthalate Exposure Modulates Antioxidant Enzyme Activity and Gene Expression in Juvenile and Adult Daphnia magna. Archives of Environmental Contamination \& Toxicology 75:1-12.

Wittassek M, Koch HM, Angerer J, and Brüning T. 2011. Assessing exposure to phthalates - the human biomonitoring approach. Molecular Nutrition \& Food Research 55:7-31.

Xiang N, Zhao C, Diao X, Han Q, and Zhou H. 2017. Dynamic responses of antioxidant enzymes in pearl oyster Pinctada martensii exposed to di(2-ethylhexyl) phthalate (DEHP). Environ Toxicol Pharmacol 54:184-190.

Xing H, Li S, Wang Z, Gao X, Xu S, and Wang X. 2012. Histopathological changes and antioxidant response in brain and kidney of common carp exposed to atrazine and chlorpyrifos. Chemosphere 88:377-383.

Xu H, Dong X, Zhang Z, Yang M, Wu X, Liu H, Lao Q, and Li C. 2015. Assessment of immunotoxicity of dibutyl phthalate using live zebrafish embryos. Fish \& Shellfish Immunology 45:286.

Zeng F, Wen J, Cui K, Wu L, Liu M, Li Y, Lin Y, Zhu F, Ma Z, and Zeng Z. 2009. Seasonal distribution of phthalate esters in surface water of the urban lakes in the subtropical city, Guangzhou, China. Journal of Hazardous Materials 169:719-725. 
580 Zhang ZM, Zhang HH, Zou YW, and Yang GP. 2018. Distribution and ecotoxicological state of 581 phthalate esters in the sea-surface microlayer, seawater and sediment of the Bohai Sea and the Yellow Sea is. Environmental Pollution 240:235.

Zhao X, Gao Y, and Qi M. 2014. Toxicity of phthalate esters exposure to carp (Cyprinus carpio) and antioxidant response by biomarker. Ecotoxicology 23:626-632.

Zheng Q, Feng M, and Dai Y. 2013. Comparative antioxidant responses in liver of Carassius auratus exposed to phthalates: An integrated biomarker approach. Environmental Toxicology \& Pharmacology 36:741-749.

Zhou QH, Wu ZB, Cheng SP, He F, and Fu GP. 2005. Enzymatic activities in constructed wetlands and di- n -butyl phthalate (DBP) biodegradation. Soil Biology \& Biochemistry 37:1454-1459. 


\section{Table $\mathbf{1}$ (on next page)}

Table 1 Acute toxicity responses of neonate and adult $D$. magna exposed to DBP.

Note: Accumulated mortality (\%) of neonatal and adult D. magna exposed to various DBP concentrations for 24 and $48 \mathrm{~h}$ and the $\mathrm{LC}_{50}$ with $95 \%$ confidence limits, were calculated by Probit analysis using SPSS 21 . In the regression equation, the logarithm of concentration was indicated by $X$ and the mortality of $D$. magna was indicated by $Y$. 


\begin{tabular}{|c|c|c|c|c|c|c|c|}
\hline $\begin{array}{l}\text { Age } \\
\text { Group }\end{array}$ & Time (h) & $\begin{array}{c}\text { Regression } \\
\text { equation }\end{array}$ & $\begin{array}{c}\text { Correlation } \\
\text { coefficient } \\
\mathbf{R}^{2}\end{array}$ & $\begin{array}{c}\mathrm{LC}_{50} \\
(\mathrm{mg} / \mathrm{L})\end{array}$ & $\begin{array}{c}95 \% \\
\text { Confidence } \\
\text { interval }\end{array}$ & $\begin{array}{c}\text { Safe } \\
\text { concentratio } \\
n(\mathrm{mg} / \mathrm{L})\end{array}$ & $\begin{array}{c}\text { Replicates } \\
\text { /trials }\end{array}$ \\
\hline \multirow{2}{*}{ Neonate } & 24 & $y=-1.819+3.361 x$ & 0.998 & 3.48 & $3.09-3.99$ & \multirow[t]{2}{*}{0.56} & $5 / 2$ \\
\hline & 48 & $y=-1.414+2.523 x$ & 0.992 & 2.83 & $2.42-3.33$ & & $5 / 2$ \\
\hline \multirow[b]{2}{*}{ Adult } & 24 & $y=-2.185+3.008 x$ & 0.991 & 4.92 & $4.22-6.32$ & \multirow{2}{*}{0.98} & $5 / 2$ \\
\hline & 48 & $y=-1.254+1.798 x$ & 0.972 & 4.31 & $3.50-6.03$ & & $5 / 2$ \\
\hline
\end{tabular}


Figure 1

DBP induced change in $D$. magna $\mathrm{H}_{2} \mathrm{O}_{2}$ concentrations.

(a) neonates and (b) adults, following exposure to 0.5 and $2.0 \mathrm{mg} / \mathrm{L}$ DBP for 24 and $48 \mathrm{~h}$. Capital letters $(A / B / C)$ indicate the difference between the $0,0.5$, and $2.0 \mathrm{mg} / \mathrm{L}$ DBP treatment groups at $48 \mathrm{~h}$. Lowercase letters $(\mathrm{a} / \mathrm{b} / \mathrm{c})$ indicate the difference between the 0 , 0.5 , and $2.0 \mathrm{mg} / \mathrm{L}$ DBP treatment groups at $24 \mathrm{~h}$. Different letters indicate significant differences between the DBP treatments. The error bars are standard deviation $(n=4)$
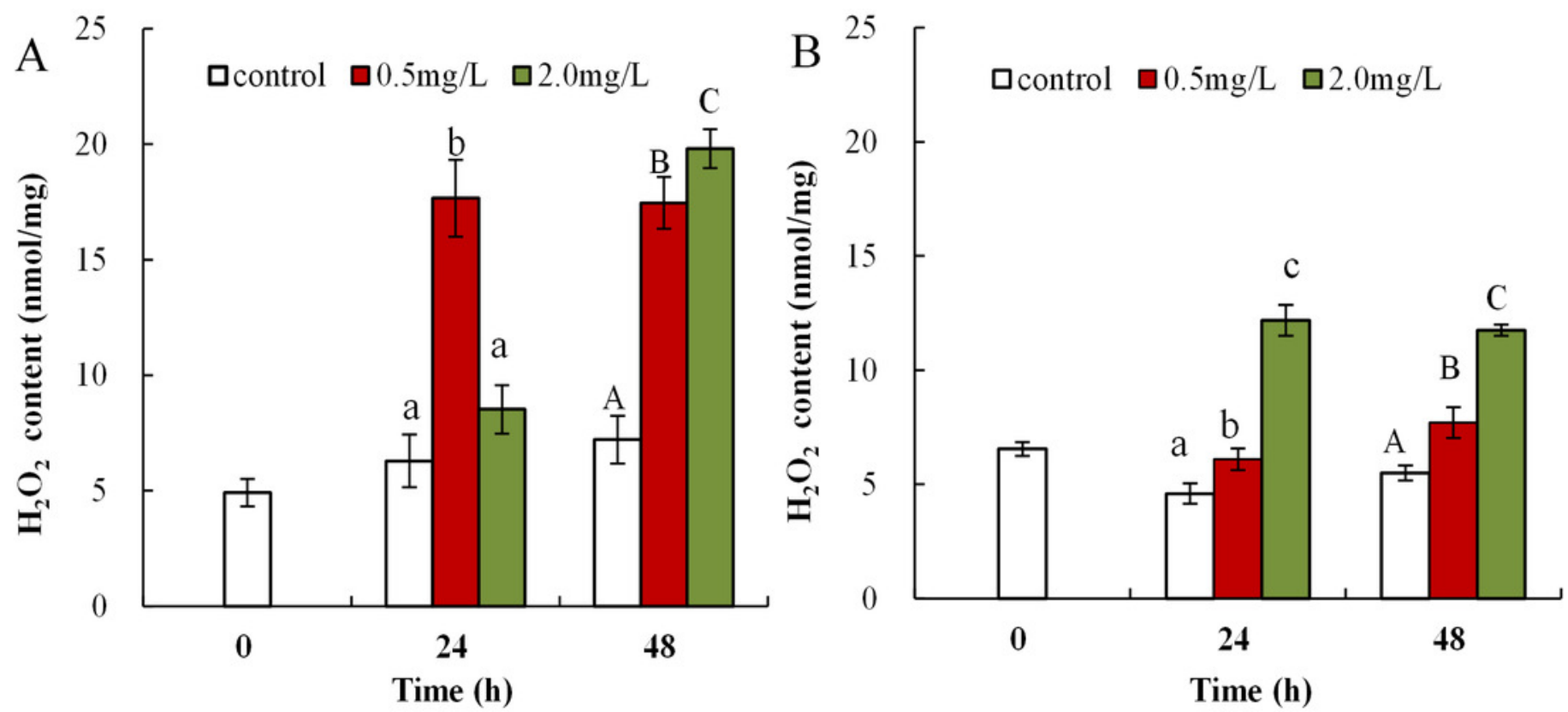
Figure 2

DBP induced lipid peroxidation in D. magna.

(a) neonates and (b) adults, following exposure to 0.5 and $2.0 \mathrm{mg} / \mathrm{L}$ DBP for 24 and $48 \mathrm{~h}$. Capital letters $(\mathrm{A} / \mathrm{B} / \mathrm{C})$ indicate the difference between the $0,0.5$, and $2.0 \mathrm{mg} / \mathrm{L}$ DBP treatment groups at $48 \mathrm{~h}$. Lowercase letters $(\mathrm{a} / \mathrm{b} / \mathrm{c})$ indicate the difference between the 0 , 0.5, and $2.0 \mathrm{mg} / \mathrm{L}$ DBP treatment groups at $24 \mathrm{~h}$. Different letters indicate significant differences between the DBP treatments. The error bars are standard deviation $(n=4)$

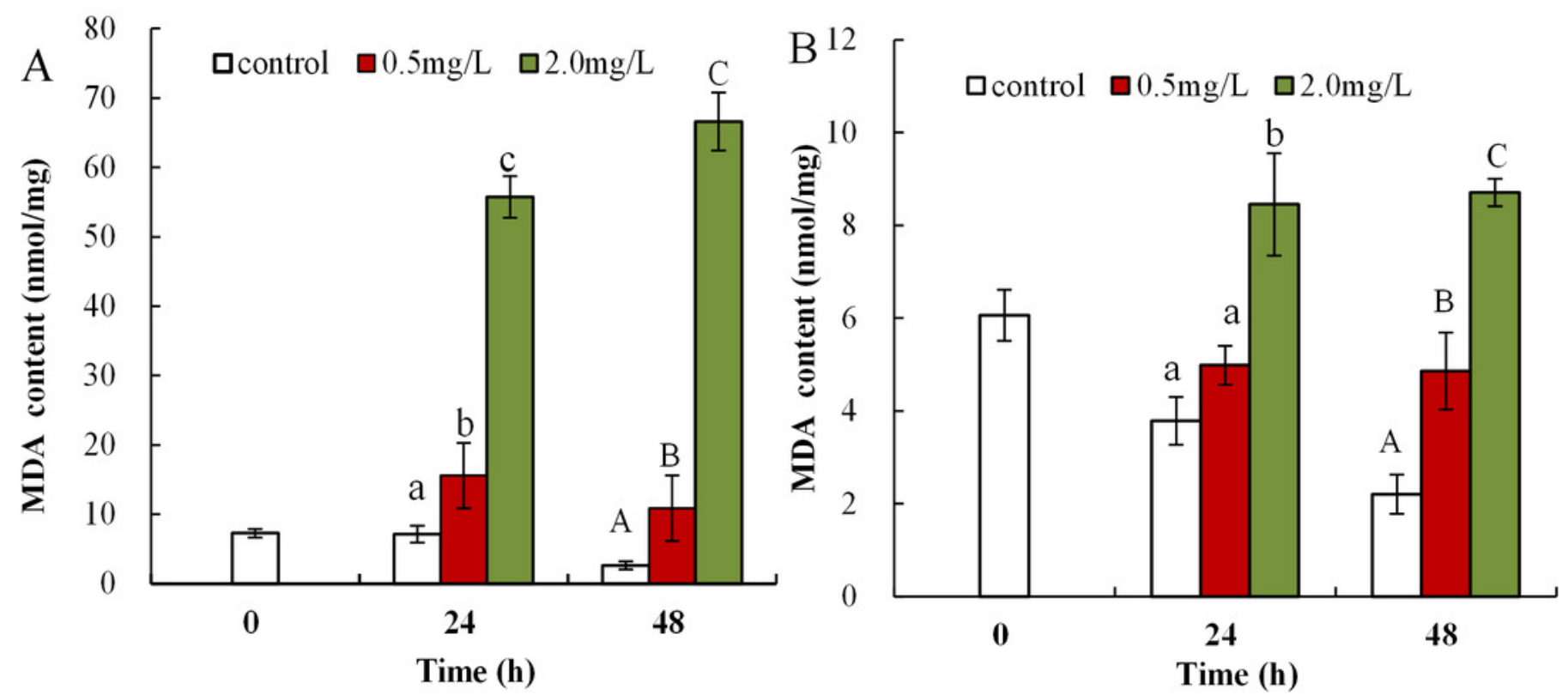


Figure 3

DBP induced changes of T-AOC in D. magna.

(a) neonates and (b) adults, following exposure to 0.5 and $2.0 \mathrm{mg} / \mathrm{L}$ DBP for 24 and $48 \mathrm{~h}$. Capital letters $(\mathrm{A} / \mathrm{B} / \mathrm{C})$ indicate the difference between the $0,0.5$, and $2.0 \mathrm{mg} / \mathrm{L} \mathrm{DBP}$ treatment groups at $48 \mathrm{~h}$. Lowercase letters $(\mathrm{a} / \mathrm{b} / \mathrm{c})$ indicate the difference between the 0 , 0.5, and $2.0 \mathrm{mg} / \mathrm{L} \mathrm{DBP}$ treatment groups at $24 \mathrm{~h}$. Different letters indicate significant differences between the DBP treatments. The error bars are standard deviation $(n=4)$
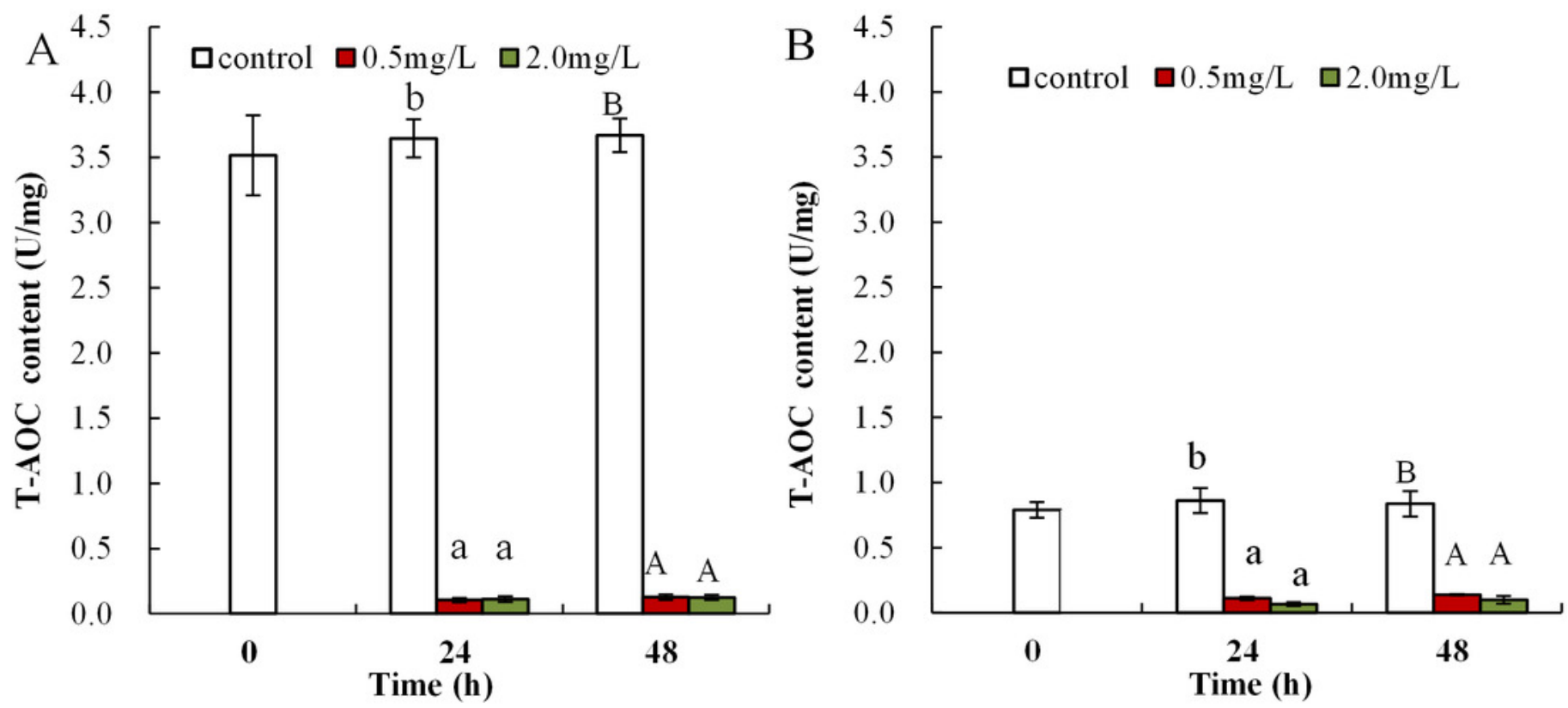


\section{Figure 4}

DBP induced changes in SOD activity in D. magna.

(a) neonates and (b) adults, following exposure to 0.5 and $2.0 \mathrm{mg} / \mathrm{L}$ DBP for 24 and $48 \mathrm{~h}$. Capital letters $(A / B / C)$ indicate the difference between the $0,0.5$, and $2.0 \mathrm{mg} / \mathrm{L}$ DBP treatment groups at $48 \mathrm{~h}$. Lowercase letters $(\mathrm{a} / \mathrm{b} / \mathrm{c})$ indicate the difference between the 0 , 0.5 , and $2.0 \mathrm{mg} / \mathrm{L} \mathrm{DBP}$ treatment groups at $24 \mathrm{~h}$. Different letters indicate significant differences between the DBP treatments. The error bars are standard deviation $(n=4)$
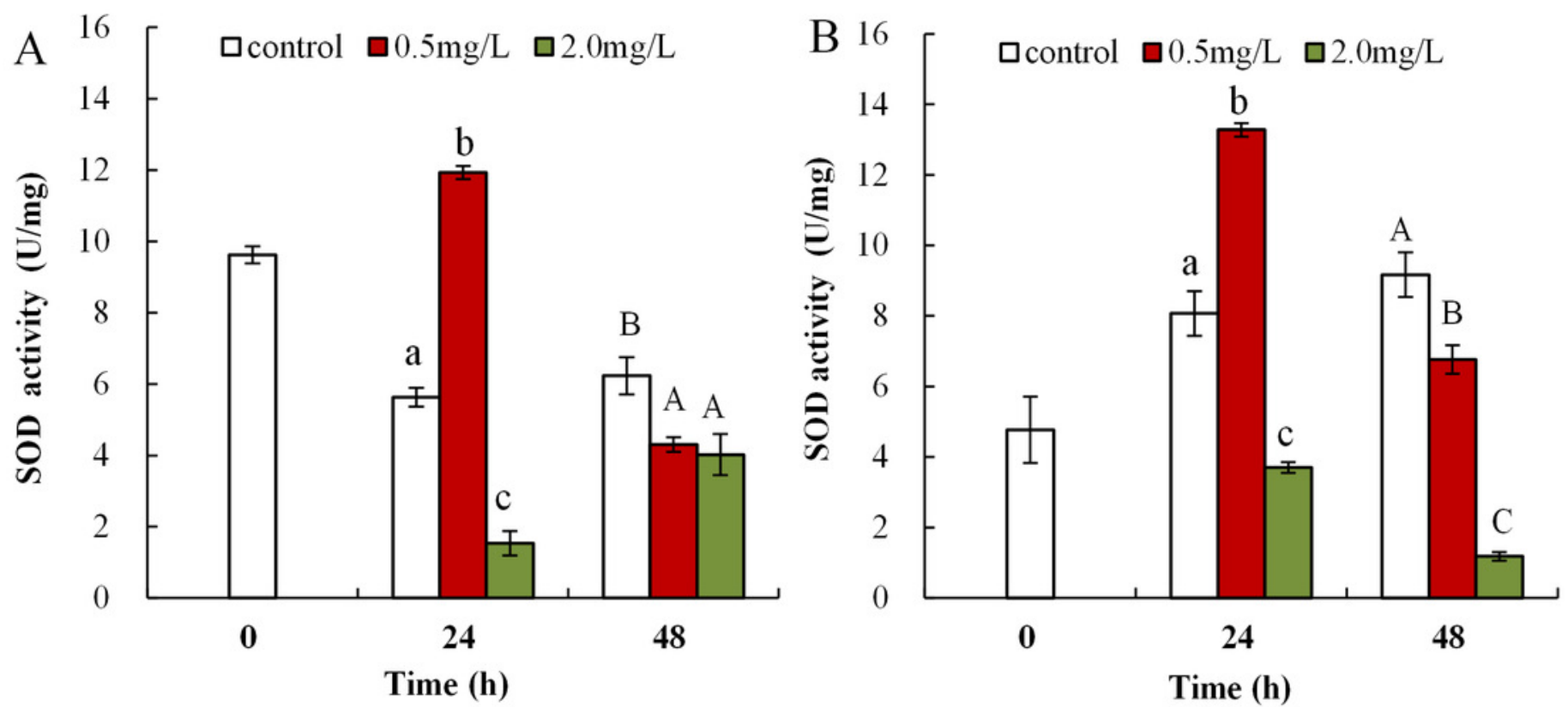
Figure 5

DBP induced changes in CAT activity in D. magna.

(a) neonates and (b) adults, following exposure to 0.5 and $2.0 \mathrm{mg} / \mathrm{L}$ DBP for 24 and $48 \mathrm{~h}$. Capital letters $(\mathrm{A} / \mathrm{B} / \mathrm{C})$ indicate the difference between the $0,0.5$, and $2.0 \mathrm{mg} / \mathrm{L} \mathrm{DBP}$ treatment groups at $48 \mathrm{~h}$. Lowercase letters $(\mathrm{a} / \mathrm{b} / \mathrm{c})$ indicate the difference between the 0 , 0.5, and $2.0 \mathrm{mg} / \mathrm{L}$ DBP treatment groups at $24 \mathrm{~h}$. Different letters indicate significant differences between the DBP treatments. The error bars are standard deviation $(n=4)$
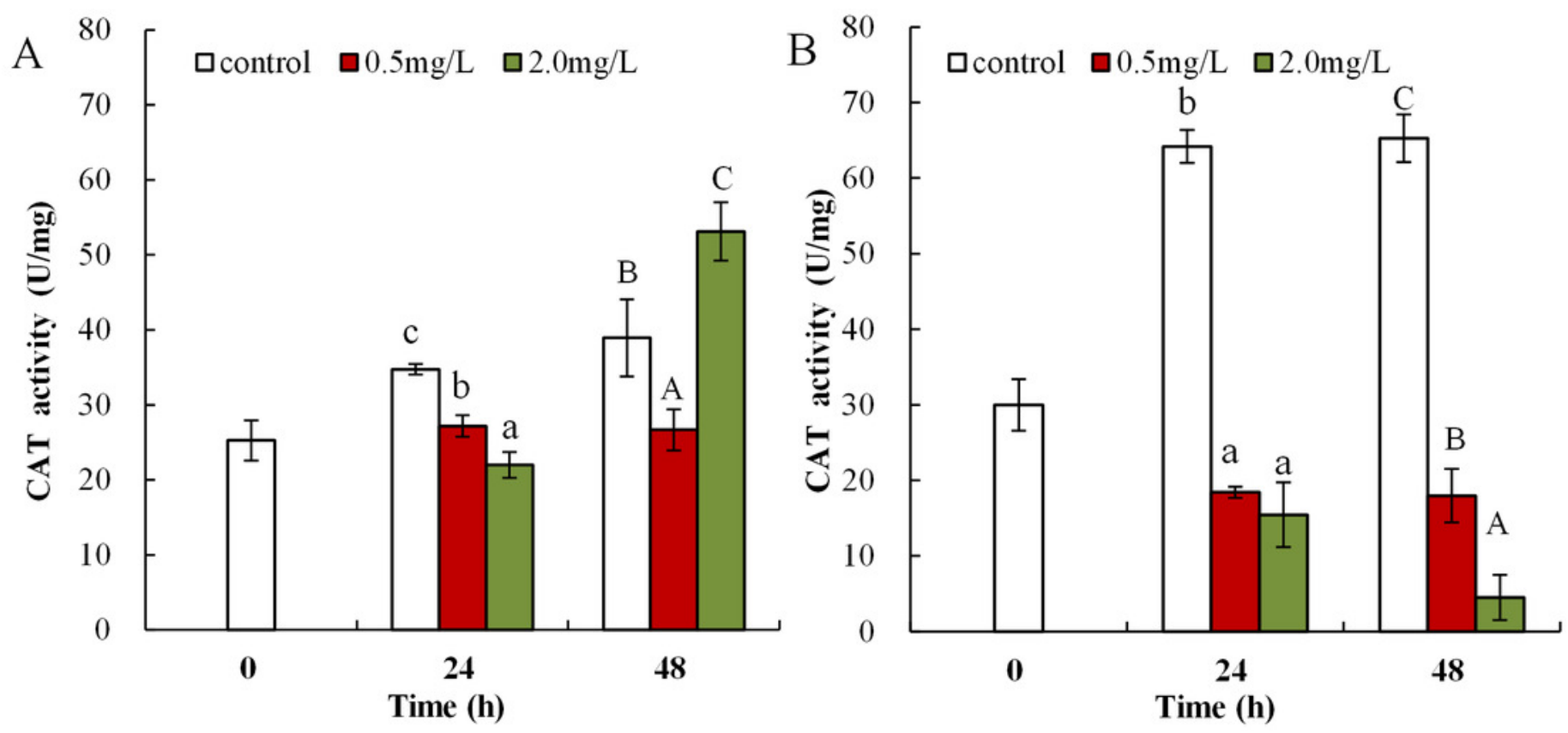
Figure 6

DBP induced change in GST in $D$. magna.

(a) neonates and (b) adults, following exposure to 0.5 and $2.0 \mathrm{mg} / \mathrm{L}$ DBP for 24 and $48 \mathrm{~h}$. Capital letters $(A / B / C)$ indicate the difference between the $0,0.5$, and $2.0 \mathrm{mg} / \mathrm{L}$ DBP treatment groups at $48 \mathrm{~h}$. Lowercase letters $(\mathrm{a} / \mathrm{b} / \mathrm{c})$ indicate the difference between the 0 , 0.5 , and $2.0 \mathrm{mg} / \mathrm{L}$ DBP treatment groups at $24 \mathrm{~h}$. Different letters indicate significant differences between the DBP treatments. The error bars are standard deviation $(n=4)$
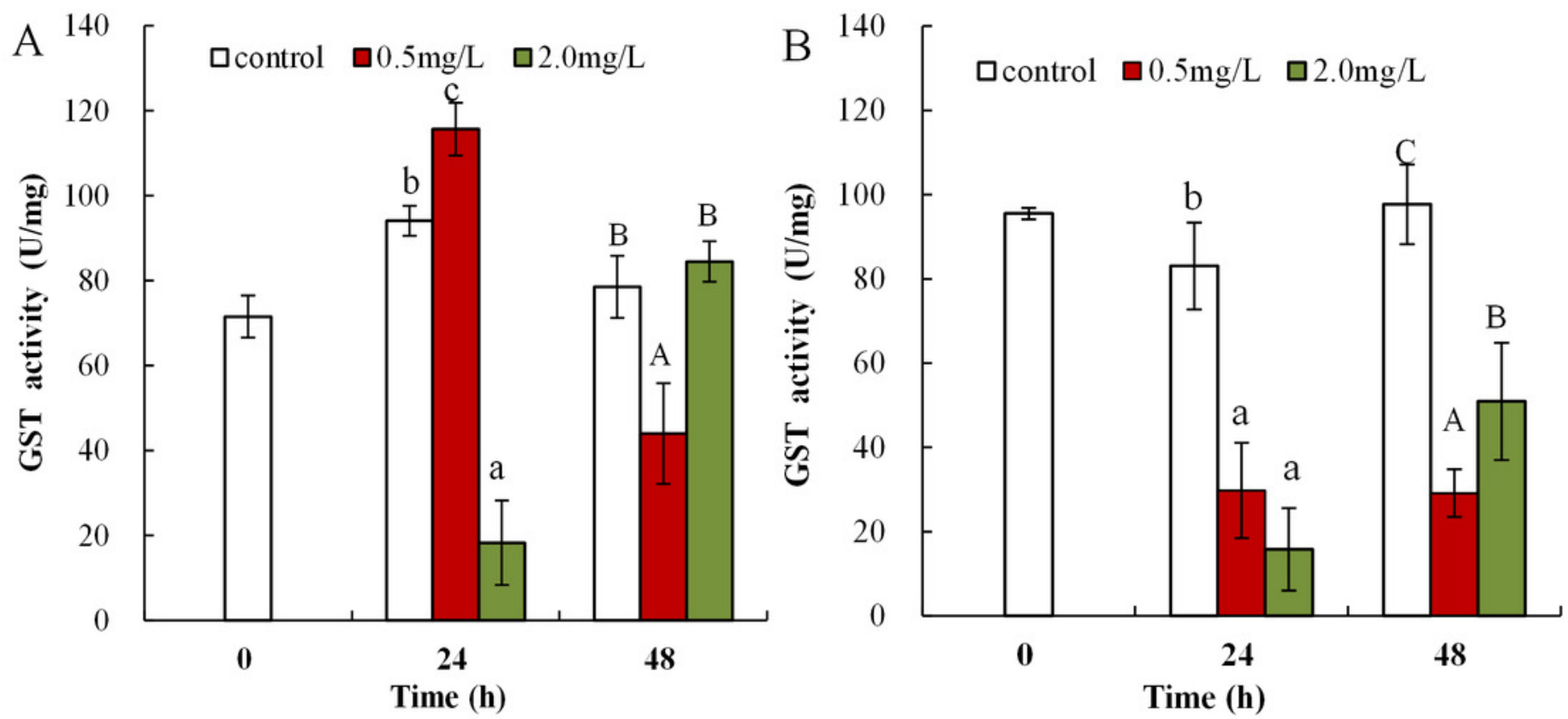